\title{
The socioeconomic and technical status of cut flower producers in Tabasco, Mexico
}

\author{
María I. Saldaña y Hernández ${ }^{1}$, Regino Gómez², Juan M. Pat², José D. \\ Álvarez ${ }^{2}$, Julián Pérez ${ }^{3}$, and Carlos F. Ortiz \\ ${ }^{1}$ Instituto Tecnológico de la Zona Olmeca. Zaragoza s/n. Villa Ocuiltzapotlan, Centro, Tabasco, C.P. 86270. \\ Mexico. \\ ${ }^{2}$ Colegio de la Frontera Sur. Unidad Villahermosa. Carretera Villahermosa-Reforma Km 15.5 El Guineo \\ $2^{\mathrm{a}} \mathrm{Sec}$. C.P. 86280. Villahermosa, Tabasco. Mexico. \\ ${ }^{3}$ Colegio de Postgraduados, Campus Tabasco. Km 3.5 Periférico, H. Cárdenas, Tabasco. C.P. 86500. Mexico.
}

\begin{abstract}
M.I. Saldaña y Hernández, R. Gómez, J.M. Pat, J.D. Álvarez, J. Pérez, and C.F. Ortiz. 2013. The socioeconomic and technical status of cut flower producers in Tabasco, México. Cien. Inv. Agr. 40(1):5-15. Floriculture in Tabasco, Mexico is part of a diversification and increasing agricultural income, which has the potential for outstanding growth. To determine the socioeconomic status as well as the technical advancement of this sector, surveys were conducted of cut flower producers and combined with official statistics. Socioeconomic and technological indicators showed that $38 \%$ of the producers had a high standard of living and $69 \%$ of farmers had three or more years of experience in flower cultivation. Most farmers owned their land $(66 \%)$, and their educational attainment was above the national average. Most of the producers did not depend exclusively on their revenues from flowers. The average income for a cultivated area was $\$ 936.33 \mathrm{USD} \mathrm{ha}^{-1} \cdot \mathrm{yr}^{-1}$. The technological level and management of the plantations was very different among farms. The yield and quality of the production could be improved through improved handling of weeds, watering and drainage. Plant diseases and pests are not restricting growth at this time. Currently, only $11 \%$ of the production is marketed, which means that a national and international market needs to be developed. In addition, it was found that the infrastructure for watering, production and postharvest is insufficient to develop the activity for the export market.
\end{abstract}

Key words: Florists, socioeconomic levels, technological usage, tropical flowers.

\section{Introduction}

Worldwide cut flower production has had a constant yearly growth rate of $6 \%$ (Rodríguez et al., 2007). The main markets are the United States, the Netherlands, Japan, Germany and

Received March 17, 2012. Accepted October 9, 2012. Corresponding author: regomez@ecosur.mx
England, which combined represent $85 \%$ of the global market (Granada, 2009). In the Americas, the main producers and exporters are Colombia (52\%), Ecuador (17\%), Mexico (4\%) and Costa Rica (3\%) (Proexport Colombia, 2003). Mexico has 11,310 ha of land devoted to cut flower and greenery production (Rodríguez et al., 2007). Demand for traditional species has diversified to include exotic tropical species, including orchids, 
flamingo flowers, birds of paradise, heliconias and gingers (López et al., 2006).

Commercial planting of tropical flowers started 20 years ago in Tabasco, and according to Criley and Broschat (1992), Tabasco has the proper edaphoclimatic conditions for their harvest. Production, harvest, post-harvest, packing, transport and distribution processes have great potential for growth as a source of rural work and income generation. There is lack of basic information about socioeconomic and productive characteristics of this sector. Therefore, the objective of this study was to determine the socioeconomic and technical status of cut flowers producers in Tabasco.

\section{Materials and methods}

The research was carried out in Tabasco, Southeast México. It is located between $17^{\circ} 19^{\prime} 00^{\prime \prime}$ and $18^{\circ} 39^{\prime} 00^{\prime \prime}$ North latitude and $90^{\circ} 57^{\prime} 00^{\prime \prime}$ and $94^{\circ} 08^{\prime} 00^{\prime \prime}$ West longitude. The three geopolitical regions included in the study were Chontalpa, Centro and Sierra. The weather is warm, with an annual average temperature of $26^{\circ} \mathrm{C}$; yearly rainfall is from 2,000 to $4,000 \mathrm{~mm}$; and most of the soils are of alluvial origin (INEGI, 2005). This research was conducted from July to September 2009. Socioeconomic characteristics and technology used were assessed with surveys of flower producers with production farms equal to or greater than 0.25 ha. The study included 29 flower production farms. The survey was carried out in 17 rural municipalities by Centros de Atención de Desarrollo Rural (CADER), which is part of the Secretaría de Agricultura, Ganadería, Desarrollo
Rural, Pesca y Alimentación (SAGARPA), and by the Secretaría de Desarrollo Agropecuario Forestal y Pesca (SEDAFOP). Informants were identified with the help of fellow producers, using a snowball technique. The socioeconomic status was defined with indicators of producers' social level and economic status, such as property ownership, years of schooling, number of workers, farm area and yearly income. The values for these characteristics were categorized and an overall score was calculated to define producers' socioeconomic level according to a scale (Table 1). Other socioeconomic characteristics evaluated were location, public services received, years of experience, legal status, and organization of production. The main indicators evaluated to determine technological competence were as follows: area, cultivated species, previous and associated crops, soil fertility and chemical input usage, diseases, pests, weeds, harvest, postharvest treatment, production destination and infrastructure. In order to validate information about phytosanitary issues, phytopathological analysis of four plantations was performed at the Laboratorio de Fitopatología of the Colegio de Postgraduados, Campus Tabasco (México). Infrastructure assessed was grouped as follows: hydrological (wells, irrigation systems and plot drainage), production (area for introduction of new species, greenhouses, compost, and areas for tools and pesticides), and post-harvest (areas for cleaning, packing, display, cold room, parking lot and office). The location of each production unit was recorded using GPS. This information was coupled with data from Tabasco's soil map to assess the soil type.

Table 1. Variables used to classify the socioeconomic level of cut flower producers in Tabasco, Mexico.

\begin{tabular}{llllllllllll}
\hline \multicolumn{2}{l}{ Yearly income (USD) } & Land tenure & & Education level & Employees & & \multicolumn{2}{l}{ Cultivated area (ha) } & Socioeconomic level \\
\hline $0-923.07$ & 1 & $\begin{array}{l}\text { Communal } \\
\text { land }\end{array}$ & 1 & Basic & 1 & $0-1$ & 1 & $0.25-1$ & 1 & $1-5$ & Low \\
& & & & & & & & & & \\
$923.07-4230.77$ & 2 & Rented & 2 & Medium & 2 & $2-4$ & 2 & $>1-2$ & 2 & $>5-10$ & Medium \\
$>4230.77$ & 3 & Private & 3 & Superior & 3 & $>4$ & 3 & $>2$ & 3 & $>10$ & High \\
\hline
\end{tabular}

Source: Data obtained from surveys. 
Phytopathological analysis. To understand the presence of diseases in cultivated species, sampling was carried out in farms located in Hermenegildo Galeana, Teapa; Melchor Ocampo, Cárdenas; and Norte, Comalcalco, Tumbulushal and Medellín y Madero, Centro, Tabasco. The sampling took place in two seasons: Autumn-Winter 2010 and Spring-Summer 2011. Leaf samples, rhizomes and roots with evidence of disease were collected. Durex tape, histological cuts and potato-dextroseagar were used to identify the causal agents of observed disease.

Statistical analysis. Data was analyzed using statistical tests including normal distribution, mean, standard deviation and $X^{2}$ (Chi squared test).

\section{Results and discussion}

\section{Socioeconomic characteristics}

Production location. There are 29 cut flower farms in Tabasco. Each farm is a managed by one person. The cultivation of cut flowers is performed in nine of 17 municipalities, including the three geopolitical regions of Chontalpa, Centro and Sierra Regions. Plantations are located from 3 masl (meters above sea level) in Paraíso, up to 102.5 masl in Tacotalpa.
Most of the flower farms are located in Teapa, Centro and Comalcalco, and they represent $82 \%$ of cultivated flower area in Tabasco (Table 2).

Services. The flower farms in Tabasco are agroforestry systems that take advantage of plant species of great biological and economic value. These farms are also potential destinations for agricultural tourism. In the future, the producer's quality of life and the diversification of their income will depend to a great extent on the services they can offer visitors and consumers interested in rural tourism and the ecosystem services they can provide. Farmers had limited access to public services including potable water $(69 \%)$, electricity (59\%), access roads $(66 \%)$ and sewers (38\%); these values were correlated $\left(X^{2}\right.$ $\alpha=0.075)$.The access of services is below the average level reported for Tabasco, which are potable water (72\%), electricity $(96.7 \%)$ and sewers $97.8 \%$ (INEGI, 2011). It is important to mention that improving technology must correspond with current trends in sustainable agriculture and must consider the fragility of tropical ecosystems. Adding innovative technologies such as rainfall water reservoirs, solar energy, ecological waste disposal, and biodigesters using supplies available in rural areas will avoid dependence on external agents and reduce risk to natural resources.

Table 2. Area cultivated for cut flowers in Tabasco, Mexico.

\begin{tabular}{llcrrrr}
\hline Municipality & Farms & Elevation & $\begin{array}{r}\text { Area } \\
\text { Total } \\
\text { (ha) }\end{array}$ & Average & SD & Percentage \\
\hline Cárdenas & 1 & $11.0 \pm 0$ & 2.00 & 2.0 & 0 & 1.80 \\
Centro & 4 & $11.6 \pm 11.32$ & 28.00 & 7.0 & 4.4 & 25.20 \\
Comalcalco & 6 & $13.8 \pm 8.73$ & 17.25 & 2.8 & 2.2 & 15.53 \\
Cunduacán & 3 & $9.1 \pm 2.16$ & 1.50 & 0.7 & 0.2 & 1.35 \\
Jalapa & 1 & $21.0 \pm 0$ & 5.00 & 5.0 & 0 & 4.50 \\
Macuspana & 1 & $25.0 \pm 0$ & 3.60 & 3.6 & 0 & 3.24 \\
Paraíso & 1 & $3.0 \pm 0$ & 0.75 & 0.8 & 0 & 0.68 \\
Tacotalpa & 5 & $102.0 \pm 60.8$ & 6.50 & 1.3 & 0.6 & 5.85 \\
Teapa & 7 & $37.7 \pm 22.1$ & 46.50 & 6.6 & 7.0 & 41.85 \\
Total & 29 & & 111.10 & 3.3 & & 100 \\
\hline
\end{tabular}

Source: Data obtained from surveys. 
Years of experience and education. Of the producers surveyed, $31 \%$ had between one and two years of experience, $14 \%$ had 3 to 5 years and $55 \%$ had more than 5 years of experience growing flowers. As for education, $70 \%$ of producers had a bachelor's degree or other higher academic training; this percentage is twice the average education level of the country (INEGI, 2009). Years of experience were related to years of education $\left(X^{2} \alpha=0.03\right)$. All producers $(100 \%)$ with more than 10 years of experience had a bachelor's degree. Of producers with less than 10 years of experience, $53 \%$ had a bachelor's degree, $23.5 \%$ had graduated high school or junior high school, and $23.5 \%$ had only finished elementary school or attended elementary school. These results indicate that this activity has been carried out by relatively highly educated producers.

Land ownership and legal status. As for land ownership, $66 \%$ were private owners, $24 \%$ were communal producers, and $10 \%$ were lessees. Private producers were the first to adopt growing ornamental flower crops. According to the OAS (2006), a secure private property regime provides security for producers and incentives to take risks to promote rural development. As for the legal status for operation and taxes to the STA (Service of Tributary Administration), $83 \%$ of flower producers were individuals and $17 \%$ were associations (three Rural Production Societies and one Civil Association). There is no relationship between the type of property and the legal organization that the producers decided to use ( $\left.X^{2} \alpha=0.76\right)$. Individuals had the largest (76 $\%)$ number of privately owned plantations and are part of the formal sector of the economy.

Organization of production. To carry out the productive activities of their farms, $63 \%$ of producers said they were internally organized for production, and 37\% were not. Nevertheless, their organization is incipient, as there are still knowledge gaps including cultivated species and varieties, planting density, yield, flower availability through year, investment quantities, scheduling of activities for pest control, diseases, weeds and harvest. Lack of organization in ornamental production systems leads to plantations having inadequate processing, a lack of standardization and reduced flower quality; these patterns are repeated in the cut flower production systems in several Latin American countries (USAID, 2007). Currently, producers are not organized to sell flowers wholesale because they lack access to credit and community services. When surveyed, only $9 \%$ of producers had obtained credit, and only $12 \%$ had obtained individualized technical advice.

Floriculture's contribution to family income: The percentage of cut flower producers that received income from the sale of cut flowers was $60 \%$, while $40 \%$ received no income because their plantations are not yet producing or they had no market. Producers earned an average income of

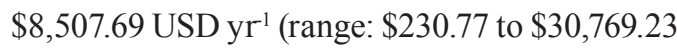
USD, SD \$9,628.64). In comparison to the annual minimum wage, $20 \%$ of farmers received less than the minimum wage, $33 \%$ received 1 to 3 times the minimum wage, $20 \%$ received 4 to 6 times the minimum wage, and $27 \%$ received more than six times the minimum annual wage. With respect to annual income by farm area, the average income was $\$ 1,936.33$ USD ha $^{-1} \mathrm{yr}^{-1}$ (ranging from $\$ 57.69$ to $\$ 7,692.31 \mathrm{USD} \mathrm{ha}^{-1} \mathrm{yr}^{-1}$, SD \$2,124). In Tabasco, papaya (Carica papaya L.) cultivation earns more money, according to SIAP (2011), with papaya growers receiving an average income of $\$ 9,326.88 \mathrm{USD}$ ha $\mathrm{yr}^{-1}$, which is 4.8 times higher than that obtained by flower producers.

Producer's socioeconomic level. Flower producers can be divided into three social levels (Table 1), $48 \%$ in the low level, $14 \%$ in the medium level and $38 \%$ in the high level. Socioeconomic status is related to income variables, property type, level of education, number of jobs created and cultivated area $\left(X^{2} \alpha=0.0029\right)$. 


\section{Technical-productive characteristics}

Surface and cultivated species: There are 111.1 ha planted with ornamental cut flowers in Tabasco, and at the national level, there are 11,310 ha of cut flowers and greenery, including temperate and tropical zones (Rodríguez et al., 2007). The average area cultivated per producer in Tabasco is 3.85 ha (SD 4.66). There are 26 species of flowers grown (Table 3). The fifteen Heliconia and eight Zingiberaceae species cultivated in Tabasco represent $6 \%$ and $0.6 \%$, respectively, of the 250 and 1300 species reported for each of those groups worldwide (López et al. 2006). Twenty of the cultivated species are large, five are medium, and one is small.

Previous cultivars and species associated with flower plantations. Tropical cut flowers need shade to grow. To develop flower plantations, producers used two strategies: 1) plant under the canopy of cocoa plantations (39\%), forest trees (19\%) and fruits trees other than cocoa (23\%); and 2) when the producers did not have plantations that could provide shade, they reforested grasslands before planting flowers (19\%). Currently, $54 \%$ of the farms were associated with forest, $35 \%$ were associated with cocoa, and $11 \%$ were associated with fruit trees other than cacao. There is a highly significant relationship between the planting of previous crops and flower plantations $\left(X^{2} \alpha=0.005\right)$. Fruit and forest species used for reforestation that are now associated with tropical flowers include rambutan (Nephelium lappaceum L.), cedar (Cedrela odorata L.), mahogany (Swietenia macrophyla King.), maquilishuat (Tabebuia rosea (Bertol.) A.DC.), earpod tree (Enterolobium cyclocarpum (Jacq.) Griseb.) and monkey pod (Pithecellobium saman (Jacq.) Benth.). In all cases, land use changes have been directed to grow trees with several purposes in addition to providing shade for ornamental cultivars, such as producing fine wood, fruit, firewood or improved soil conditions. Therefore, ornamental agroecosystems are considered to act as a factor that slows "detrimental development", which has been common in Tabasco during recent decades (Tudela, 1992); Tabasco is currently ranked as the third most damaged state in terms of natural resources nationwide (SEMARNAT-CP, 2002).

Soils fertility and nutrient deficiencies. Ornamental cut flowers in Tabasco are found in eight different soil subunits. Fluvisol eutric is the predominant soil type (Table 4). Distribution of cultivated lands for cut flowers in Tabasco is a clear example of the general status of the rural sector in Latin America (Barkin, 1998), where colonization consisted of continuous displacements of inhabitants of profitable lands, who were forced to work in areas not wellsuited to certain kinds of production. There is an owner-polarized system in this region, where the most fertile crop lands are held by flower producers of high socioeconomic levels and the poorer soils are used by producers of the lower social sectors. Most of the producers, 93\%, did not know the soil's nutrient characteristics. This knowledge would increase their potential to efficiently fertilize the land for effective plant growth. With regard to nutrient deficiencies, $28 \%$ of producers believed they did not have problems, $31 \%$ said they had problems, and $41 \%$ did not know about this issue. In efforts to correct nutrient deficiencies, farmers use triple 17, urea and potassium chloride.

Diseases and their importance. The survey revealed producers' perceptions of disease: $48 \%$ of producers indicated that they have no diseases in their plantations; $42 \%$ stated they had diseases; and $10 \%$ were unaware of them. Producers said that when diseases arise they were very severe $(64 \%)$, severe $(7 \%)$ and moderate $(29 \%)$; $16 \%$ of producers tried to control diseases with copper sulfate, promil, terramycin, garlic and chamomile. Phytopathological analysis revealed the presence of several diseases. Rust was found from Puccinia sp. Liberato et al. (2008), which was found in $P$. heliconiae in Papua New Guinea. Pardo (2006) and Villalobos et al. (2009) report rust in Colombia and Costa Rica. Leaf spots were 
Table 3. Species of cut flowers cultivated in Tabasco, Mexico.

\begin{tabular}{|c|c|}
\hline Name & Common name \\
\hline \multicolumn{2}{|l|}{ Family Heliconiaceae } \\
\hline Heliconia bihai ${ }^{1}$ & Filo de la noche \\
\hline H. bourgueana & Bourgueana \\
\hline H. caribe & Caribe \\
\hline H. champneiana $\mathrm{cv}$. Maya blood & Sangre maya \\
\hline H. champneiana $\mathrm{cv}$. Maya gold & Oro maya \\
\hline H. champneiana cv. Splash & Splash \\
\hline H. chartacea cv. Sexy pink & Sexy pink \\
\hline H. collinsiana ${ }^{1}$ & Colinsiana \\
\hline H. latispatha & Platanillo \\
\hline H. ortotricha $\mathrm{cv}$. She & She velloso \\
\hline H. psittacorum cv. Choconiana & Avecita choconiana \\
\hline H. psittacorum cv. Fire opale ${ }^{1}$ & Fair opal \\
\hline H. psittacorum cv. Fuchsia ${ }^{1}$ & Avecita fiucha \\
\hline H. psittacorum cv. Sassy & Avecita Sasy \\
\hline H. psittacorum cv. St. Vincent red ${ }^{1}$ & Rojo San Vicente \\
\hline H. psittacorum cv.Kathy ${ }^{1}$ & Katy \\
\hline H. psittacorum $x$ H. spathocircinata $\mathrm{cv}$. Golden Torch ${ }^{1}$ & Antorcha dorada \\
\hline H. psittacorum $x$ H. spathocircinata cv. Golden Torch Adriano ${ }^{1}$ & Adriano \\
\hline H. rauliana & Rauliana \\
\hline H. rostrata & Rostrata \\
\hline H. secunda ${ }^{1}$ & Tucán \\
\hline H. spissa cv. Guatemala Yellow & Amarillo Guatemala \\
\hline H. sppissa cv. Mexico red & Rojo México \\
\hline H. stricta & Iris red \\
\hline H. stricta cv. Dwarf Jamaican & Jamaica \\
\hline H. stricta $\mathrm{cv}$. Tagami & Tagami \\
\hline H. wagneriana $\mathrm{cv}$. Peterson & Wagneriana \\
\hline \multicolumn{2}{|l|}{ Family Zingiberaceae } \\
\hline Alpinia purpurata var. $\operatorname{Red}^{1}$ & Ginger roja \\
\hline A. purpurata var. pink & Ginger rosa \\
\hline A. purpurata var. Anne Hironaka & Ginger blanca \\
\hline A. speciosa & Boquita de tiburón \\
\hline Costus pulverulentus & Cabeza de indio \\
\hline Curcuma sumatrana & Curcuma \\
\hline Etlingera elatior var. Red Torch ${ }^{1}$ & Bastón del Emperador Rojo \\
\hline Tapeinochilos ananassae & Indonesia \\
\hline Zingiber zerumbet $\mathrm{cv}$. Variegated & Maraca roja \\
\hline Z. spectabile sp. Golden Septor & Maraca amarilla \\
\hline \multicolumn{2}{|l|}{ Family Marantaceae } \\
\hline Calathea crotalifera & Hoja de To verde \\
\hline C. lutea & Hoja de To blanca \\
\hline \multicolumn{2}{|l|}{ Family Musaceae } \\
\hline Musa coccinea var. Royal Red & Musa roja \\
\hline M. ornata $\mathrm{cv}$. Pink & Musa rosa \\
\hline M. velutina & Musa velutina \\
\hline
\end{tabular}

${ }^{1}$ Species commercially cultivated.

Source: Data obtained from surveys. 
Table 4. Soil subunits and area cultivated for cut flowers in Tabasco, Mexico.

\begin{tabular}{lccl}
\hline Soil subunits $^{1}$ & Surface $^{2}($ ha) & Percentage $^{2}(\%)$ & Aptitude $^{1}$ \\
\hline Arenosol haplic & 0.75 & 0.7 & Normal \\
Fluvisol eutric & 43.5 & 39.2 & High \\
Gleysol eutric & 2.0 & 1.8 & High \\
Gleysol mollic & 23.5 & 21.2 & High \\
Leptosol rendzic & 3.1 & 2.8 & High \\
Luvisol chromic & 9.0 & 8.1 & Less normal \\
Vertisol eutric & 27.25 & 24.5 & High \\
Vertisol cromic & 2.0 & 1.8 & Less normal \\
Total & 111.10 & 100.0 & \\
\hline
\end{tabular}

Source: ${ }^{1}$ Palma-López et al. (2007); ${ }^{2}$ Data obtained from surveys.

another disease, which was caused by Cordana sp., Helminthosporium sp., Pyriculariopsis sp., Curvularia sp., Lasiodiplodia sp., Periconia sp. Roya in association with H. secunda, H. psittacorum cvs. Golden Torch, Andromeda and Fuchia, $H$. stricta $\mathrm{cv}$. Tagami and $H$. collinsiana. These species were reported by Alarcón (2007) in Colombia with high levels of incidence. Bacteria were also found, including Ralstonia solanacearum race 2, which was confirmed in $H$. wagneriana $\mathrm{cv}$. Cream and found in Centro and Comalcalco. This bacterium causes bacterial wilt or Moko disease on Musa and Heliconia (Alarcón, 2007; Lins and Coelho, 2004). There were also nematodes. Meloidogyne sp. was identified in five municipalities, with the highest incidence (9\%) in A. purpurata cv. Pink in Tumbulushal, Centro, which was same incidence level reported by Alarcón (2007). Lins and Coelho (2004) found A. purpurata to be the most susceptible to Meloidogyne incognita, with an incidence rate of $70 \%$. The autumn-winter season had 2.5 times more plantations with phytosanitary problems than spring-summer.

Pests. When asked about pests, $69 \%$ of producers reported pests, and $31 \%$ did not report any. The percentage of farmers reporting pests were: 67\% - ants (Family: Formicidae), 11\% - true bugs (Family: Coreidae), 11\% - mealybugs (Family: Pseudococcidae), 9\% - beetles (Family: Scarabaeidae), and 2\% - whiteflies (Family: Aleyrodidae). For vertebrate pests, $7 \%$ of farmers reported gophers (Family: Geomidae). The infestation levels were assessed by the farmers as low $(83 \%)$, medium $(11 \%)$ and unaware $(6 \%)$. The damage reported by the producers was in the foliage (44\%), flower and foliage (22\%), flower $(11 \%)$, root $(17 \%)$ and whole plant $(6 \%) .83 \%$ of the producers considered the infestation levels to be below the mean, $11 \%$ considered the levels to be at the mean, and $6 \%$ unaware about this information. Producers who mentioned that they had pests controlled them using cypermethrin, chlorpyrifos, malathion, monocrotophos, methyl parathion, neem and garlic extracts.

The fact that the majority of producers reported the absence of diseases and pests and/or low levels of incidence and infestation could be because of how they have developed their ornamental production system, where the heterogeneity and complexity of the agroecosystem promotes the natural control of phytopathogen organisms, favoring predators and antagonist species (Lin, 2011).

Weed control. The high rate of weeds growing in humid tropics can cost farmers significant time and effort to control. Efforts are required for sustainable management that reduces the use of herbicides and allows for the conservation and improvement of the soil. Weed control is a common practice of flower producers, with all producers performing some weed control. The majority (66\%) of producers controlled weeds by 
hand (machete), and some (34\%) used chemicals. The presence of weeds in the plantations and their control was highly related ( $\left.X^{2} \alpha=0.00004\right)$. The main herbicides were glyphosate and paraquat.

Harvest. The harvest of cut flowers in Tabasco is a result of demand from the local and regional markets. The producer only harvests when he has a specific market demand guaranteed. The unit typically sold in the market is a dozen. Of the producers interviewed, $60 \%$ had harvested flowers in multiples of this unit for sale. The harvest was performed in 72.9 ha $(68 \%$ of the cultivated area), while $32 \%$ do not harvest because their plantations had not reached a productive stage or they did not have a market. The volume harvested is 601 dozen ha $\mathrm{h}^{-1} \mathrm{yr}^{-1}$. However, Tabasco has the potential to produce 5,416 dozen $\cdot \mathrm{ha}^{-1} \cdot \mathrm{yr}^{-1}$ (De las Heras, 2012. Personal communication. Asociación de Productores de Flores y Follajes Tropicales S. de R.L. de C.V. Tabasco, México). Currently, flower producers only harvest $11 \%$ of their productive capacity.

Post-harvest treatment. One hundred percent of producers applied post-harvest treatments to their flower, such as cleaning with water as a natural treatment. Producers used pesticide 3\% of the time, and no one used wax. The levels of post-harvest treatment found are similar to those reported by ALTROPICO (2005) for tropical flowers in Latin America.

Production destination. Producers of ornamental flowers have entered the market with varied results; $60 \%$ sold their production in a continuous or sporadic manner, while $40 \%$ did not sell because they have not found a market or their plantations had not reached a productive stage. Of the 17 flower producers that sold their products, the plurality sells their product locally (42\%) and some sell at a regional scale $(10 \%)$, with the national market being the smallest $(8 \%)$. With the exception of two producers who design flower bouquets (Tropiflor S.P.R. de R.L. and Tanay Trópico), all others sell their production as raw material with no added value. One obvious conclusion from the data is that an increased market value chain and improved access to markets could be developed to assure that the product can reach the final consumer, whether it is a flower shop or supermarket; there is also the potential to generate partnerships with transport or shipment companies and venture into production of certified ecological flowers.

\section{Actual technological usage}

Of total cut flower producers, $58 \%$ had some type of infrastructure and $42 \%$ do not have infrastructure in their plantations, which is a condition that limits efficient production.

Hydrological infrastructure. In some flower farms in Tabasco, there were irrigation systems, wells and plot drainage; $38 \%$ of plantations had irrigation systems, and $62 \%$ did not. In terms of surface area, 34\% (38 ha) of the plantation area for flower production had irrigation; these areas were dedicated to production of heliconias and gingers in an alluvial prairie and wetland, where flat lands allow irrigation systems to satisfy crop requirements during the dry season (March, April and May). However, it is necessary to be able to quickly drain large amounts of rainfall water during the wet season (September, October, November) because excess water can be more detrimental than a water shortage for flower production; $47 \%$ of producers had plot drainage systems, and 53\% reported that they did not have them. There was no relationship among hydrological infrastructure, years of experience, socioeconomic level and producer income $\left(X^{2} \alpha=0.67\right)$.

Production infrastructure. Of 29 flower farms, 15 had warehouses for tools, nine had an area reserved for new species, eight had a warehouse exclusively for pesticides, five had a compost area, and three had a greenhouse. These conditions indicate heterogeneity of production technology and a need to find strategies to transfer technologies. There was no relationship between productive 
infrastructure and a producer's socioeconomic level $\left(X^{2} \alpha=0.75\right)$

Post-harvest Infrastructure. The survey showed that of 29 flower productive farms, $24 \%$ had a cleaning and packing area. Also, 10 flower producers had vehicles to transport their product. Tropical flower production in Tabasco is done in an open pit with a minimum of infrastructure similar to other tropical zones of Mexico, as reported by Baltazar and Figueroa (2009). This infrastructure differs from flower production systems in temperate regions, where $74 \%$ of producers used protection for their crops (Murguía and Lee, 2007).

Results indicate that the plantations of cut flowers in Tabasco are distributed across the expansive plains, reaching up to mountain areas. Because $85 \%$ of the cultivated area is highly suitable for these plants, the edaphic conditions are good for their commercial exploitation.

Production of cut flowers in Tabasco is a growing industry using agroforestry systems. At the moment, there are no major restrictions posed by phytosanitary and nutrient concerns under these conditions. Nevertheless, it is recommended that healthy propagation material be used to avoid the dissemination of Meloidogyne and Ralstonia solanacearum race 2 . The management of the land's fertility should be carried out based on the analyses of its physical and chemical characteristics and the requirements of the plant being cultivated, allowing for more efficient use of fertilizers. Despite more than 10 years of productive experience for $37 \%$ of the producers, the area planted with flowers remains small. The socioeconomic level, education level and type of property showed that the sector is made up of people who have a higher standard of living than the general population. Currently, producers with low economic resources are starting plantations with government support. This policy has been developed to provide an alternative source of employment and income for rural areas. Such support should have continuity to avoid problems of developing markets and supply chains. The current producers only market $11 \%$ of the productive potential of their plantations. The development of the market for their products requires improving the quality of the product by training the producers.

It is also necessary to develop the capacities of the producers to diversify their revenues from flower agroecosystems. For example, strategies could include alternatives such as agrotourism. The effective organization and participation of producers will be needed to form a strong base for the sustainable development of the production capacity of this sector.

\section{Acknowledgments}

We are thankful for the financing provided by the Fondo Mixto CONACYT-Gobierno del Estado de Tabasco and the support of the Asociación de Productores de Flores y Follajes Tropicales S. de R.L. de C.V. (project TAB-2008-C011-8811).

\section{Resumen}

M.I. Saldaña y Hernández, R. Gómez, J.M. Pat, J.D. Álvarez, J. Pérez, y C.F. Ortiz. 2013. Nivel socioeconómico y tecnológico de los productores de flor de corte en Tabasco, México. Cien. Inv. Agr. 40(1):5-15. La floricultura en Tabasco, México, forma parte de un plan de diversificación para incrementar ingresos agrícolas con expectativas alentadoras. Para conocer aspectos socioeconómicos y técnico-productivos del sector, se aplicaron encuestas a productores a partir de información oficial, para generar un padrón de floricultores. Los indicadores socioeconómicos y tecnológicos utilizados, demostraron que el 38\% de los productores corresponden a un nivel socioeconómico alto, $69 \%$ cuentan con tres a más de 
10 años de experiencia en sus cultivos, son propietarios de su tierra $66 \%$ y tienen niveles de escolaridad superiores al promedio nacional. La mayoría de los productores no dependen exclusivamente de los ingresos de esta actividad. El promedio de ingreso por superficie cultivada es de $\$ 936.33$ USD ha $^{-1}$ año ${ }^{-1}$. El nivel tecnológico y manejo de las plantaciones es muy variado entre las unidades de producción. Los rendimientos y calidad de la producción son susceptibles de mejora a través del manejo oportuno de malezas, riego y drenaje. Las enfermedades y plagas no son limitantes por el momento. Sólo se comercializa el $11 \%$ de la producción, por lo que se requiere desarrollar el mercado nacional e internacional. No obstante, la infraestructura hidráulica, productiva y de poscosecha es insuficiente para desarrollar la actividad con miras a la exportación.

Palabras clave: Flores tropicales, floricultores, niveles socioeconómicos, uso de la tecnología.

\section{References}

Alarcón, J. 2007. Enfermedades en la producción de Heliconias en los Departamentos de Caldas, Risaralda y Quindío. Agron. 15:45-61.

ALTROPICO. 2005. Estudio de mercado local para flores tropicales con potencial comercial y productivo desde la Zona de Chical. Conservación en áreas indígenas manejadas. Ecuador, USAID/ BIOFOR Consortium: $31 \mathrm{pp}$. Available online at: http://pdf.usaid.gov/pdf_docs/PNADE069.pdf (Website accessed: November 4, 2009).

Baltazar, B.O., and K.A. Figueroa. 2009. Flores que atrapan tu mirada. Estudio de vida de florero y comercial de flores ornamentales de la Zona Centro del Estado de Veracruz. Colegio de Postgraduados. México. 80 pp.

Barkin, D. 1998. Riqueza, pobreza y desarrollo sostenible. México: Editorial Jus y Centro de Ecología y Desarrollo. 43 pp. Available online at: www.ambiente.gov.ar/infotecaea/barkin02. pdf (Website accessed October 23, 2011).

Criley, R.A., and T.K. Broschat. 1992. Heliconia: Botany and Horticulture of a New Floral Crop. Journal Series No. 3563 of the Hawaii Institute of Tropical Agriculture and Human Resources. 55 p.

Granada, C.L. 2009. Situación actual de la producción de ornamentales en México; retos y oportunidades. Memoria electrónica. Primer Simposium Experiencias exitosas de empresas ornamentales y tendencias del mercado. Ornato 2009. Universidad Veracruzana. Facultad de ciencias biológicas y agropecuarias. Región Orizaba-Córdoba. 19 octubre. Córdoba, Veracruz, México.

INEGI. 2005. Anuario estadístico de Tabasco. INEGI (Instituto Nacional de Estadística Geografía e Informática) y Gobierno del estado de Tabasco. Aguascalientes, Aguascalientes, México. 547 pp. INEGI. 2009. México hoy. Aguascalientes. INEGI (Instituto Nacional de Estadística Geografía e Informática). Aguascalientes, México. 292 pp.

INEGI. 2011. Censo de población y vivienda Tabasco 2010. Available online at: www.inegi.org.mx (Website accessed: March 20, 2012).

Liberato, J., J. Ray, and T. Gunua. 2008. Puccinia heliconiae on Heliconia sp. in Papua New Guinea. Australian Plant Disease Notes 3:132-134.

Lin, B. 2011. Resilience in Agriculture through crop diversification: Adaptative management for environmental changes. BioScience 61:183-193.

Lins, S.R.O., and R.S.B. Coelho. 2004. Ocorrênce de doenças em plantas ornamentalis tropicais no estado de Pernambuco. Fitopatologia Brasileira 29:332-335.

López, A., J. Pérez, C. Sosa-Moss, J.M. Mejía, and L. Bucio. 2006. El cultivo de las plantas ornamentales tropicales. Gobierno del Estado de Tabasco. Instituto para el Desarrollo de Sistemas de producción de Trópico Húmedo de Tabasco. Colegio de Postgraduados. Tabasco, México. $105 \mathrm{pp}$.

Murguía, G.J., and E.H. Lee. 2007. La horticultura ornamental en el estado de Veracruz, México. Actas de Horticultura. Sociedad Española de Ciencias Hortícolas 48:485-488. 
OAS. 2006. Tenencia de la tierra, compartiendo información y experiencias para la sostenibilidad. OAS (Organization of the American States). Serie de políticas No. 10. Washington D.C. USA. Available online at: www.oas.org/dsd/policy series/10_spa.pdf (Website accessed: August 20, 2012).

Palma-López, D.J., J. Cisneros, E. Moreno, and J.A. Rincón-Ramírez. 2007. Suelos de Tabasco: Su uso y manejo sustentable. Colegio de PostgraduadosISPROTAB-FUPROTAB. Villahermosa, Tabasco, México. 195 pp.

Pardo, V. 2006. Uredinales de plantas cultivadas de interés floral en Colombia. Revista de la Facultad Nacional de Agronomía Medellín 59:3335-3353.

Proexport Colombia. 2003. Estudio de mercado. Mariposas en el Estado de California-Estados Unidos. Convenio específico No. 197.1/2003. Proexport Colombia e Instituto Alexander von Humboldt. Bogotá, Colombia. 106 pp. Available online at: www.minambiente.gov.co/.../331_ estudio_de_heliconias_pdf (Website accessed: November 4, 2009).

Rodríguez, M.N., L.I. Trejo-Téllez, and F. FernándezLuqueño. 2007. Flores de corte. Manual de producción. Ediciones Papiro Omega. México. $126 \mathrm{pp}$.

SEMARNAT-CP. 2002. Evaluación de la degradación de la tierra causada por el hombre en la república mexicana. Escala 1:250,000. SEMARNAT-CP
(Secretaría del Medio Ambiente y Recursos Naturales-Colegio de Postgraduados), Memoria Nacional. Montecillo, México. 68 pp.

SIAP. 2011. Producción agrícola por cultivo 2011. SIAP (Servicio de Información Agropecuaria). Available online at: www.siap.gob.mx/index (Website accessed: February 20, 2012).

Tudela, F. 1992. La modernización forzada del trópico: el caso de Tabasco, proyecto integrado del Golfo. Centro de Investigación y de Estudios Avanzados del Instituto Politécnico Nacional, Federación Internacional de Institutos para Estudios Avanzados, Instituto de Investigaciones de las Naciones Unidas para el Desarrollo Social, Colegio de México A.C. México, D.F. 475 pp.

USAID. 2007. Actividad rural competitiva. Flores tropicales para la exportación. USAID (Agencia de los Estados Unidos para el Desarrollo Internacional). La Paz Bolivia. 47 pp. Available online at: http://pdf.usaid.gov/pdf_docs/ PNADN939.pdf (Website accessed: November 4, 2011).

Villalobos, J., F. Cárdenas, and J. Cordero. 2009. Lista de enfermedades de los cultivos agrícolas y forestales de Costa Rica, 2009. San José Costa Rica. Ministerio de Agricultura y GanaderíaServicio Fitosanitario del Estado-Diagnóstico Fitosanitario. 130 pp. 
